\title{
Social Sciences Teachers' Opinions on Usage of Educational Information Network
}

\author{
Burcu Sezginsoy Seker ${ }^{1, *}$, Filiz Tuba Dikkartın Övez ${ }^{2}$ \\ ${ }^{1}$ Education Faculty of Necatibey, Primary School Education Balikesir University, Balıkesir, 10100, Turkey \\ ${ }^{2}$ Education Faculty of Necatibey, Secondary Science and Mathematics Education, Balikesir University, Bal1kesir, 10100, Turkey
}

Copyright $(\mathrm{C} 2018$ by authors, all rights reserved. Authors agree that this article remains permanently open access under the terms of the Creative Commons Attribution License 4.0 International License

\begin{abstract}
The aim of the study is to put forth the opinions of social studies teacher on the usage of Education Informatics Network (EIN). In accordance with this objective, 60 social studies teachers who work in secondary education institutions affiliated to Ministry of National Education in the various cities of Turkey form the sample group of the study. The volunteered teachers who attended the in-service trainings named "Teaching Methods and Techniques in Social Studies and EIN" which were held by Ministry of National Education form the sample group of the research. As data collection tool, "EIN Opinion Scale" which was developed by researchers and was composed of open-ended questions was used. The data obtained from the scale was analysed via conduct analysis method. According to the results of the study; it was found that most of the social studies teachers use EIN in order to provide document, they don't use EIN to upload content, they just use it to provide information only. It was also seen that they consider themselves inadequate on the subject of developing content and they don't use Content Management System mostly.
\end{abstract}

Keywords Education Informatics Network, Opinions of Social Science Teachers, Usage of Technology in Education

\section{Introduction}

The aim of social studies at primary and secondary schools has been determined as: to gain knowledge of past, present and future experiences of humanity, to improve their thinking skills, democratic values and attitudes and to provide opportunities for more social participation [1]. In teaching social studies, it is also important to provide the student with scientific perspective and to develop his/her high-level thinking skills. The renewed Social Studies Program has been prepared with the intention of training active human types who are avantgarde, open to science, technology and to innovations these have brought, effective, productive, questioning, able to handle the problems in different ways and solve the problems they encountered [2]. The importance the program gives to science and technology is stated in the overall objectives of the program. According to Social Studies curriculum, students should use information and communication technologies by understanding the development process of science and technology and their effects on social life. For this reason, the use of information technologies, especially in support of the educational programs implemented in schools, and their integration into these programs have become important for learning both inside and outside the school.

The rapid increase in information technologies and the effective use of technological tools that have become diversified in parallel to this increase, especially by digital natives [3] either in Turkey or in the world requires a change in educational environments and teachers today. Working either in the regulation of educational environments or in the management of these environments, teachers need to become able to respond to the needs of technology. Technology has an important place to ensure progress in education. That is why trainers need to integrate the use of technology with their own field of study and they need the educational environments to realize it [4]. The skills the teachers require to have in Information and Communication Technologies in General Qualifications of Teaching Profession are determined as; being a technology literate, being able to follow the developments in Information and Communication Technologies (ICT), being able to benefit from ICT in order to support his/her professional development and increase his/her productivity, being able to benefit from ICT for sharing information purposes, being able to prepare appropriate learning environments for students who have different experiences, characteristics and skills by also using ICT, being able to give a place in the course program on how to use ICT, being able to benefit from computers and other technological tools in material preparation, being able to 
access sources related to teaching-learning in technological environments (databases, online sources, etc.), being able to evaluate them in terms of their accuracy and suitability, being able to be a model in effective use of technology sources and being able to teach them, being able to use technologies that support student-based strategies by taking into account the different needs of the students, being able to develop and implement strategies for behaviour management in technology- intensive environments, being able to inform parents, school management and other trainers on results by using ICT [2]. In this context, teachers have to keep their knowledge and skills constantly up-to-date in parallel with new developments and realize their information technology use effectively in the classroom. In the social studies course which adopts the aim of raising qualified citizens, it is necessary to have teachers of social studies who integrate technology with social studies, benefit from multimedia programs and motivate their students and also make them gain and develop the skills of decision making, problem solving, critical and creative thinking [5].

Studies on the integration of information and communication technologies in education in Turkey continue rapidly. Especially, within the scope of the FATIH (Action to Increase Opportunities and Improve Technology) project, by giving to each classroom a smart board, a laptop and a colour printer and providing a computer aided education, the e-content created will be transmitted to the students. Fatih Project basically consists of five main components. These components are named as; i. Hardware and software infrastructure, ii. Providing and managing the e-content, iii. Effective use of ICT in educational programs; iv. Conscious, safe, manageable and measurable use of ICT and internet; v. In-service training for teachers for the use of ICT in courses.

Educational Information Network (EIN) is an online social education platform which has been created and conducted by General Directorate of Innovation and Education Technologies within the scope of "Providing and Managing e-content" which is one of the sub-components of the FATIH project [5]. One of the biggest parts of the Fatih Project, EIN, is based on producing digital materials and content and it is aimed to provide the integration of computerized communication technologies in education this way. Within the scope of EIN, e-contents consist of information items and learning items such as of e-books, videos, presentations, animations, e-exams, interactive maps and z-books designed to include all multimedia tools. EIN, created by General Directorate of Innovation and Education Technologies as an online social education platform within the scope of "Providing and Managing e-content" which is one of the basic components of the Fatih Project, aims to provide reliable and effective contents needed both for teachers and students inside and outside school. The concept of social networking is defined as communities created on the
Internet that enable people to share their thoughts and facilitate interaction with each other towards a common goal. According to Tinmaz [7] the role of social networks is "to provide a network of people connected to one another in the field of education", such as in the social field, "when they need each other and information". As social networking platforms quickly become widespread and accessible, people's connections with each other become stronger. It has been shown that social networking sites encourage active learning and collaborative work when used for educational purposes [8]. For example; Selwyn [9] argues that social networks "allow students to build new collaborative learning networks and that this can provide benefit for students."

EIN is a project of expandable web applications which is able to carry the entire educational informatics system which is formed by blending the dynamic systems of the age such as search engine, social network, e-encyclopaedia with the purpose of popularize the information culture in education with a systematic and planned policy and to meet the educational information needs [6]. Designed for all stakeholders of education particularly teachers and students, EIN is a social education platform that aims to offer different, rich and educative contents, provide that information culture is popularized and used in education, responds to needs related to the content, support information exchange, contribute to the courses with its rich and ever-growing archive, aims to re-structure information while learning it, covering students having different learning styles (verbal, visual, numerical, social, individual, aural learning), bringing together all teachers in a common ground and providing that they direct education in cooperation, designed with the intention of using technology as a tool not as a purpose $[5,10]$.

Many countries of the world develop policies for the integration of technology in education such as EIN, an online social education platform named Educational Information Network (EIN), in order to turn into an opportunity of active usage of technology in daily life and make projects oriented at online social education platforms. At the beginning of these studies is the use of interactive whiteboards. Many k-12s and colleges in the US and UK also made significant investments in interactive whiteboard technology [11]. Interactive whiteboards are also actively used in Australian schools following the British education system [12].

Interactive training platforms such as EIN and similar applications are applied in various countries in order to correspond the cost of the budget allocated for the technological infrastructure works, e-content needs and to support technological integration. In this context, Turkey which promotes technology integration in education with Fatih projects by EIN platform is among the five OECD countries which is working and developed policies in this direction [13].

Open educational resources (OER) are one of these 
resources. UNESCO and Commonwealth of Learning Open Educational Resources are teaching, learning and research materials in any medium, digital or otherwise, that resides in the public domain or has been released under an open license that permits no cost access, use, adaptation and redistribution by others with no or limited restrictions [14].

OER, designed as an open learning resource to help students with using high quality educational content and materials, allows availability to OER educational contents and free access to sharing opportunities [15]. It has also influenced the projects and supports of international organizations and OER Turkish education system and has been effective in the establishment of EIN.

In addition, OER has become a fundamental component of open teaching in higher education settings [16]. OERs contain a wide range of course materials, from school texts to curriculum, academic program, course notes, assignments, tests, projects, audios, videos and animations. The OER system, which has become especially popular in higher education and has become a trend, is being used as open source in more than 40 countries as well as universities in South Africa Singapore, USA, UK and Indonesia. The availability of openly accessible content allows academicians and learners to take advantage of the wide range of content and subjects offered by OER [17].The use of OER allows teachers to save time in class by redefining the course content and materials and customizing the course plans according to the learning needs of the students $[15,18]$. In addition, the lack of incentives, the need for time to develop new materials, the problem of the copyright protection of existing resources are described as obstacles that prevent the growth and sustainability of the OER trend [19].

When the countries of the world are examined, it appears that there are many educational portals with an important user population. In the United States, the International Technology Education Association (ITEA) has realized the "Technology for All Americans Project (TfAAP)", which encompasses all children in school age in 1994 with the worldwide spread of technology. Khan Academy, founded by Salman Khan in 2006, has become the world's most important free education portal. The portal developed in this context has been translated into 40 languages including Turkish. The Khan Academy offers a personalized educational board with practical exercises, educational videos and video tutorials that allow students to study at their own pace both inside and outside the classroom. It includes many disciplines such as mathematics, science, computer programming, history, art history, and economics. This leads the way to the students from the kindergarten to the university with using interactive technological resources. Also, it also develops special contents by getting into a partnership with institutions such as NASA, Museum of Modern Art, the California Academy of Sciences, and MIT [20].Discovery Education is an educational platform that offers equal educational opportunities for students in rural school districts in the United States. It includes; interactive digital school books, interesting program compatible contents, assessment and evaluation materials and learning communities.

In Portugal, "Magellan Program", defined as one of the world's most comprehensive educational technology programs, was implemented. The aim of this program, implemented in 2007 , is to equip 850.000 students and teachers with special laptops and broadband internet connections in 2010. Since students are parts of the project, children have been included in a comprehensive orientation program throughout the country. Within the scope of the project, students can access interactive educational resources through the website prepared by intel and translated into Portuguese and named skoool.pt, Skoool.pt is a digital learning network with an interactive resource for teachers to improve their work and facilitate access to information for students. It provides basic education and digital resources in the fields of mathematics, physics, chemistry and biology in the first stage [21]. Intel started Skoool technology first in England and then in Ireland in 2002, in Turkey in 2004, and in Sweden. This is continuing in Thailand, Saudi Arabia and South Africa.

In Finland, Edu.fi was set up with BIT usage project in order to develop learning environments education and make e-learning materials accessible. It has been provided that teachers and students use the e-learning materials as online. It is aimed to providing interaction, teaching according to individual learning styles, evaluation and feedback, cognitive learning and meaningful learning and collaboration for efficiency of education and management with support of BIT in education. It includes vocational education and art education beside educational materials for primary and secondary school teachers, competitions for students and up-to-date news. E-content is provided with purchases for use and opportunity to change the contents to teachers and students when necessary is provided [22].

Developed Technology Policies in Malaysia The Malaysia 2013-2025 National Education Plan is planned to exchange in educational institutions with the participation of teachers, students, parents, the private sector and other stakeholders involved in the education system. In Malaysia, Frog VLE, established with the 1BestariNet project and selected as a learning platform provider for the whole of Malaysia, has made it possible for all students to share learning resources and work with interactive course videos. In addition, through the Virtual Learning Environment (Frog VLE) accessed at the school, students can choose to study with the help of distance learning programs on the internet. Thus, without discrimination, it is aimed to ensure that BIT is a part of schools. Maximize IT integration in the education system is tried to provide and e-contents are shared by creating a virtual learning platform for use by teachers, students and parents. A video library for e-content 
has been established [23, 24].

In addition, the Scootle national digital learning network has been established within the Australian Digital Education Revolution (DER) project. Scootle is a platform that gives teachers access to more digital resources appropriate to Australian curriculum. In Australia, all teachers can access to online resources, including Scootle. It includes interactive multimedia examples, audios, photos, video sources, interactive evaluation resources [25].

In Argentina, a training plan for information and communication technologies for teachers and students in secondary education was established in 2011 under the Conectar Igualdad program. The netbooks given to the students are loaded with educational applications and pedagogical applications on the desktop. Teachers, students, and parents also have access to digital resources through the Educ.ar site. There are training materials under the titles of Audio-Interview, Text-ebook, Interactive source, Video-Project-game at different class levels in Educ.ar site. [26].

In Turkey, there are private and paid education portals such as Vitamin and Morpa campus in addition to EIN. These portals are parallel to the contents of teaching programs and prepared as educational support services for teachers and students who work online. In addition to Vitamin Turkey, it is used in countries such as Malaysia, China and Saudi Arabia. There are interactive lecturing, experiments, pilot exams, tests, educational games and various applications. The Morpa Campus is an educational platform for primary and secondary school students and their teachers to support for lessons and includes resources such as lecturing, exercises, tests, videos, homework pages, experiments, e-books. It has a fee for students and schools. Ein, both allows to teachers to produce content with a content production system and it is a platform for communication between teachers and digital material sharing platform.

With the development of cloud information technology, the storage of large data on the internet and the accessibility of these data have become possible. EIN is a powerful social education platform that offers cloud storage $1 \mathrm{~GB}$ per student and $10 \mathrm{~GB}$ per teacher. Cloud computing can strengthen exchange and collaboration between all schools, encourage the integration of teaching resources, and can realize the maximize sharing of resources on the Internet. Also, improvement of the unbalanced distribution of existing educational resources in educational information network is positive [27].

In this context, using Information technologies and EIN effectively, following the developments in the technology and guide the students in introducing new technologies, realizing efficient learning by choosing course materials appropriate to their learning situation in EIN, giving feedback independently from school and from time to time through information communication tools to their students when they need, creating effective learning materials using appropriate content development software and sharing these materials on EIN are expected from teachers [5].

It is seen that there are various studies on teachers' use of Ein and their views on EIN in the literature. According to this, classroom teachers do not use EIN frequently; notwithstanding, they think EIN is a useful, effective and productive site [28]. In addition, teachers rarely use EIN although they do not have enough knowledge about EIN. Teachers think that Eba content needs are required to be enriched and consider e-content and videos are inadequate $[29,30]$. Mathematics teachers stated that the awareness and knowledge on the content of the mathematics course in EIN is inadequate [31]. It has been shown that teachers need courses and seminars about EIN to use EIN more effectively in lessons [32].

In the study conducted by Çakmak and Taşkıran (2017), the EIN platform was evaluated from the perspective of social studies teachers. According to this, it is determined that social science teachers are generally positive about the EIN platform, consider that the EIN platform is mainly useful, and facilitate learning and teaching process. In addition, it was determined that social science teachers think that EIN is inadequate in content, that EIN allows students to learning by experiences, and help to ensure the permanence of knowledge due to experiences are given to students by using of more material. At the same time it was determined that the EIN facilitates classroom management and that it was an extremely useful platform for students to access information that would contribute to their learning and at the same time they can take the lessons at home when they did not go to school [33].

In order to be able to effectively integrate the EIN social networking platform, one of the largest parts of the Fatih Project, into this process, there is a need for qualified teachers who are open to change, literate in technology and science, specialist in their fields. In this respect, the opinions of the teachers in the application about the use of educational information network in the courses are considered important. The studies show that teachers who are able to integrate technology in teaching and succeed in the formation of technology classes have positive attitudes and opinions towards the use of technology in teaching [34]. Technology integration process is a multivariate equation. There are many obstacles in the process of integrating technology into education due to the multiplicity and effects of these variables. These obstacles include the deficiencies of teachers' knowledge on the use of technology, deficiencies in pedagogical and field knowledge, deficiencies in knowledge of how various technologies can be used and selected in teaching and in knowledge and skills in combining teaching and technology. Since the teachers' attitudes toward technology, their opinions, and the pedagogical beliefs about teaching-learning determine the attitude of the person, negative beliefs related to technology are considered to be a major obstacle in providing technological integration 
$[35,36,37]$. For this reason, the aim of the study is to reveal the opinions of social studies teachers on the use of the Educational Information Network, which was established to integrate the technology into education.

\section{Methods}

\subsection{Model of the Research}

Since, in this research, it was aimed to reveal the opinions of social studies teachers for EIN in detail, to describe them comprehensively, to explain and evaluate them and reveal the relations, if any, a special case study method was used in the context of descriptive approach. The reason for choosing this method is that it allows for the in-depth investigation of certain aspects of the problem investigated and the possibility to work in a short time [39].

\subsection{Participants}

In the context of the aim of the research, 60 social studies teachers in total from 31 provinces working in secondary schools affiliated to the Ministry of National Education in various provinces of Turkey constitute the sample of the study. The sample of the research consists of the teachers who participated in the in-service training courses on "Teaching Methods and Techniques in Social Studies" and "Fatih Project and Educational Information Network" organized by the Ministry of National Education. While the sample group was determined in the study, the maximum variation sampling method was used from the purposeful sampling methods. The aim here is to create a relatively small sample and to reflect the diversity of the individuals who may be involved in the problem studied in this sample to the maximum extent [40]. When participants were identified, the criteria such as still carrying out secondary school social studies course and having at least three years of service period were taken into consideration. In addition, teachers who have attended in-service training courses on "Fatih Project and Educational Information Network" and "Teaching Methods and Techniques in Social Studies" were preferred in terms of reaching the teachers at maximum who work in all regions and who have a certain idea about EIN. The service periods of the participants vary from 3 to 30 years. The participants also consist of social studies teachers working in $38.27 \%$ of 81 provinces located in Turkey. The demographic characteristics of the teachers participating in the study are given in Table 1, which includes the distribution according to the provinces they work in, seniority years and genders.

When Table 1 is examined, it is seen that $18.33 \%$ of the participants were female and $81.67 \%$ were male, in terms of occupational seniority, they are in a range of 6-10 years with a rate of $31.66 \%$ at the most and $11-15$ seniority years with a rate of $23.33 \%$. It is also seen that the teachers were working in 31 different provinces.

Table 1. Demographic Characteristics of Teachers

\begin{tabular}{|c|c|c|c|}
\hline & & $\mathrm{f}$ & $\%$ \\
\hline \multirow{6}{*}{ Professional Experience } & 3-5 year & 12 & 20 \\
\hline & 6-10 year & 19 & 31.66 \\
\hline & 11-15 year & 9 & 15 \\
\hline & $16-20$ year & 14 & 23.33 \\
\hline & 21-25 year & 5 & 8.34 \\
\hline & 26-30 year & 1 & 1.67 \\
\hline \multirow{2}{*}{ Gender } & Female & 11 & 18.33 \\
\hline & Male & 49 & 81.67 \\
\hline \multirow{31}{*}{ City } & Adıyaman & 2 & 3.33 \\
\hline & Eskişehir & 1 & 1.67 \\
\hline & İstanbul & 5 & 8.33 \\
\hline & Maraş & 5 & 8.33 \\
\hline & Bursa & 2 & 3.33 \\
\hline & Gazi Antep & 2 & 3.33 \\
\hline & Sivas & 2 & 3.33 \\
\hline & Şanlı Urfa & 3 & 5 \\
\hline & Trabzon & 1 & 1.67 \\
\hline & Adana & 2 & 3.33 \\
\hline & Batman & 2 & 3.33 \\
\hline & Balıkesir & 4 & 6.67 \\
\hline & Amasya & 1 & 1.67 \\
\hline & Aksaray & 1 & 1.67 \\
\hline & Rize & 1 & 1.67 \\
\hline & Kocaeli & 1 & 1.67 \\
\hline & Manisa & 1 & 1.67 \\
\hline & Denizli & 1 & 1.67 \\
\hline & Kütahya & 3 & 5 \\
\hline & Aydın & 1 & 1.67 \\
\hline & Ankara & 5 & 8.33 \\
\hline & Mardin & 1 & 1.67 \\
\hline & Kayseri & 2 & 3.33 \\
\hline & Samsun & 2 & 3.33 \\
\hline & Ordu & 1 & 1.67 \\
\hline & Karabük & 1 & 1.67 \\
\hline & Uşak & 2 & 3.33 \\
\hline & Konya & 2 & 3.33 \\
\hline & Bolu & 1 & 1.67 \\
\hline & Sakarya & 1 & 1.67 \\
\hline & Mersin & 1 & 1.67 \\
\hline
\end{tabular}

\subsection{Data Collection Tool}

In order to get the opinions of the teachers in the study, a 
literature review was conducted, and an item pool was established. For the content validity of the interview form, two social science studies expert, one assessment and measurement evaluation expert were consulted. The items forming the interview form were arranged in line with expert opinions and in accordance with the purpose of the study. In this context, 5 interview questions were determined. Questions were asked to teachers on their use of technology and their usage purposes, what EIN is and its use in teaching social studies, the purpose for which EIN was used in teaching social studies, and what deficiencies they found in EIN. In addition, questions were asked to teachers on the use of technology in teaching social studies and the frequency of use of EIN, the software they are competent to use, and the frequency and purpose of using these software.

\subsection{Data Analysis}

Each Responses to the items in the interview form were described thoroughly (using content analysis) and converted into appropriate codes and themes. Similar expressions given to answers were listed, and then it was determined how often they were used. Subsequently, the codes were collected under common headings. Codings were initially made separately, and then consistency ratios were calculated. The reliability of the study was calculated using the Reliability $=$ Consensus (Consensus + Dissensus) x100 formula and the reliability amongst codings were determined as $92 \%$. It can be said that there is consistency between codes and themes determined by researchers [41]. In order to reflect the opinions of the interviewees, direct quotations were included for the opinions.

\section{Findings}

Table 2. Technology Use in Social Studies Education

\begin{tabular}{|c|c|c|}
\hline Use & f & \% \\
\hline Frequently & 53 & 88.33 \\
\hline Occasionally & 4 & 6.67 \\
\hline Rarely & 1 & 1.67 \\
\hline Never & 2 & 3.33 \\
\hline Total & 60 & 100 \\
\hline
\end{tabular}

Tables 2 and Table 3 give frequency and percentage values of the use of technology in the teaching of social studies by teachers participating in the research and their frequency of use of EIN.

The findings obtained under the scope of the research are as follows.

Table 3. Frequency of EIN Use in Teaching Social Studies

\begin{tabular}{|c|c|c|}
\hline Use & f & \% \\
\hline Frequently & 14 & 23.30 \\
\hline Occasionally & 22 & 36.70 \\
\hline Rarely & 12 & 20 \\
\hline Never & 12 & 20 \\
\hline Total & 60 & 100 \\
\hline
\end{tabular}

When data obtained from Table 2 and Table 3 are examined, it is seen that $88.33 \%$ of teachers prefer to use technology frequently in teaching social studies, on the other hand, they use EIN frequently only at a rate of $23.30 \%$ in teaching social studies, and that $20 \%$ use EIN rarely and other $20 \%$ never use EIN. The notable difference is that teachers, who prefer to use technology at a rate of 95\% (frequently-occasionally) in teaching social studies, prefer to use EIN at only a rate of $60 \%$ (frequently -occasionally) in teaching social studies. Similar studies have shown that teachers do not have enough knowledge on EIN and that their frequency of EIN use is not sufficient [42-44].

Direct citations on the code, frequency, percentage values and opinions that arise as a result of content analysis of teachers' use of technology in teaching social studies are given in Table 4.

According to Table 4, it has been determined that the preference of the teachers of using technology in teaching social studies is intended to increase student motivation, draw attention, increase permanence, save time, ensure meaningful learning, associate subjects with daily life, ensure concretization, facilitate teaching, increase participation in the course, make the course entertaining, make evaluation, reinforce subjects, make presentation, reduce workload, ensure learning by making and experiencing, provide aural and visual support, appeal to more sense organs, appeal to different intelligence types, reduce the inadequacy of the course book, summarize the course, display videos. It was observed that teachers preferred to use technology mostly in order to facilitate the education (14.53\%). The opinion expressed by S33 in this direction is as follows:

"I use technology in the course to provide reinforcer, to facilitate the processing of the subject, and to detect what the students have learned during the evaluation phase." 
Table 4. Usage Purpose of Technology in Teaching Social Studies

\begin{tabular}{|c|c|c|c|}
\hline Code & f & $\%$ & Sample Opinion \\
\hline Increase motivation & 5 & 2.80 & $\begin{array}{l}\text { S24. I use technology to draw the attention of students, to increase motivation and to make } \\
\text { them think differently. }\end{array}$ \\
\hline Draw attention & 5 & 2.80 & $\begin{array}{l}\text { S23. I use technology to make the subject more clear and understandable, to collect the } \\
\text { interests and attention of the children by using visuals, videos, maps, images. }\end{array}$ \\
\hline Increase permanence & 19 & 10.6 & $\begin{array}{l}\text { S22. I use it to facilitate teaching and to increase permanence within the possibilities of } \\
\text { technology. }\end{array}$ \\
\hline Save time & 11 & 6.25 & $\begin{array}{l}\text { S7. The use of technology in teaching social studies, the concept maps being on the board } \\
\text { allows the lesson to be taught without waste of time. }\end{array}$ \\
\hline $\begin{array}{l}\text { Ensure meaningful } \\
\text { learning }\end{array}$ & 8 & 4.46 & $\begin{array}{l}\text { S9. I use technology in teaching social studies with the intention of teaching achievements } \\
\text { fully and meaningfully. }\end{array}$ \\
\hline $\begin{array}{l}\text { Associate subjects with } \\
\text { daily life }\end{array}$ & 4 & 2.23 & $\begin{array}{l}\text { S11. In class, I use computers, tablets, projections, etc. as a bridge to provide the } \\
\text { relationship between teaching programs and everyday life, to ensure that learned } \\
\text { information is put into practice. }\end{array}$ \\
\hline Provide concretization & 4 & 2.23 & $\begin{array}{l}\text { S38. I use technology such as presentations, photos, videos and interactive tests mostly to } \\
\text { turn the learning of students from abstract to into concrete, to enhance the permanence of } \\
\text { the learning's. }\end{array}$ \\
\hline $\begin{array}{l}\text { Increase participation to } \\
\text { course }\end{array}$ & 15 & 8.36 & $\begin{array}{l}\text { S52.The use of technology is extremely effective and useful in the learning of the course. I } \\
\text { use it to promote attention, exemplification and active participation in class. }\end{array}$ \\
\hline $\begin{array}{l}\text { Make the course } \\
\text { entertaining }\end{array}$ & 6 & 3.35 & $\begin{array}{l}\text { S42. Today, as the needs of people change, the interests and desires of the students } \\
\text { change. I use technology in courses to make the environment non monotonous and make } \\
\text { the lessons more enjoyable and meet today's expectations. }\end{array}$ \\
\hline Make evaluation & 7 & 3.91 & $\begin{array}{l}\text { S51. I use technological applications such as smart boards in the evaluation to determine if } \\
\text { information has been learned. }\end{array}$ \\
\hline Reinforce the subjects & 8 & 4.45 & $\begin{array}{l}\text { S31. I use technology on smart boards and short videos and question solutions. I use these } \\
\text { to reinforce the subject. }\end{array}$ \\
\hline Make presentation & 14 & 7.82 & S53. I use technology and projection to make presentations and solve sample tests. \\
\hline Lighten the workload & 5 & 2.80 & $\begin{array}{l}\text { S3. I use technology because it makes my work easier when I give achievements to the } \\
\text { students. }\end{array}$ \\
\hline $\begin{array}{l}\text { Ensure learning by making } \\
\text { and experiencing }\end{array}$ & 6 & 3.34 & $\begin{array}{l}\text { S6. I make use of technologies like smart board, EIN for the reason that my course is made } \\
\text { up of visual subjects and that the subjects can be concretized and learnt by making and } \\
\text { experiencing. }\end{array}$ \\
\hline $\begin{array}{l}\text { Provide aural and visual } \\
\text { support }\end{array}$ & 17 & 9.48 & $\begin{array}{l}\text { S40. I use technology to provide visual support in the course of the course and thus to } \\
\text { reach achievements in a short time. }\end{array}$ \\
\hline $\begin{array}{l}\text { Appeal to more sense } \\
\text { organs }\end{array}$ & 5 & 2.80 & $\begin{array}{l}\text { S9. I use technology to appeal to more than one senses when I transfer technologies such } \\
\text { as smart boards and presentations into the subject to make information permanent. }\end{array}$ \\
\hline $\begin{array}{l}\text { Appeal to different } \\
\text { intelligence types }\end{array}$ & 4 & 2.23 & $\begin{array}{l}\text { S20. I use technology in teaching social studies. Because with technology, I provide } \\
\text { technological support to appeal to students' different types of intelligence. }\end{array}$ \\
\hline $\begin{array}{l}\text { Reduce the inadequacy of } \\
\text { the course book }\end{array}$ & 2 & 1.11 & S13. I use Internet to provide source, to complete the shortcomings in the course book. \\
\hline Summarize the course & 5 & 2.80 & S6. I use the smart board and EIN to open the videos related to the subject. I also use \\
\hline Display video & 3 & 1.67 & \\
\hline Total & 179 & 100 & \\
\hline
\end{tabular}

Table 5. Software and Programs That Teachers Are Competent to Use

\begin{tabular}{|c|c|c|}
\hline Programs & f & $\mathbf{\%}$ \\
\hline $\begin{array}{c}\text { Office Programs (Word, } \\
\text { Excel,...) }\end{array}$ & 60 & 100 \\
\hline Antropi & 11 & 18.33 \\
\hline EIN & 19 & 31.66 \\
\hline Morpa, Okulistik & 3 & 5 \\
\hline Movie maker & 8 & 13.33 \\
\hline Dream viewer & 3 & 5 \\
\hline Flash & 9 & 15 \\
\hline Aurasma & 2 & 3.33 \\
\hline Frontpage & 1 & 1.67 \\
\hline Basic & 1 & 1.67 \\
\hline Photoshop & 2 & 3.33 \\
\hline Publish & 1 & 1.67 \\
\hline Blog & 1 & 1.67 \\
\hline
\end{tabular}

When opinions are examined, it appears that teachers conduct teaching practices usually based on a teacher-centred learning environment and prefer to use technology mainly as an auxiliary tool for the teacher in the classroom. Another question asked to the teachers is what the software are they consider themselves competent to use. The frequency and percentage values of these software are presented in Table 5.

A When Table 5 is examined, it is seen that teachers consider themselves most competent with using Office programs. In addition, it has been determined that they consider themselves competent to use ready e-content tools such as Morpa, video, blog and website creating tools, only $19(31.66 \%)$ teachers find themselves competent to use EIN. 
Table 6. The Intended Use of Software and Programs that Teachers are Competent to Use

\begin{tabular}{|c|c|c|}
\hline Purpose & f & $\%$ \\
\hline Creating Concept Map & 3 & 1.95 \\
\hline Creating Visual Material & 31 & 20.25 \\
\hline $\begin{array}{c}\text { Ensure Participation in } \\
\text { the Course }\end{array}$ & 5 & 3.26 \\
\hline Creating Puzzles & 1 & 0.65 \\
\hline Playing Games & 1 & 0.65 \\
\hline Reinforcement & 6 & 3.92 \\
\hline Preparing Presentations & 26 & 16.98 \\
\hline Preparing Questions & 10 & 6.52 \\
\hline Increasing Permanence & 11 & 7.17 \\
\hline $\begin{array}{l}\text { Ensuring Meaningful } \\
\text { Learning }\end{array}$ & 9 & 5.88 \\
\hline Drawing Attention & 12 & 7.84 \\
\hline $\begin{array}{l}\text { Making the Course } \\
\text { Entertaining }\end{array}$ & 6 & 3.92 \\
\hline Saving Time & 6 & 3.92 \\
\hline Making Evaluation & 21 & 13.73 \\
\hline Concretization & 5 & 3.26 \\
\hline Total & 153 & 100 \\
\hline
\end{tabular}

It has been determined that only 2 teachers know how to use Aurasma, one of the augmented reality tools included in the scope of innovative teaching technologies. The frequency and percentage values regarding the intended use of the tools that teachers consider themselves as competent to use in teaching social studies are given in Table 6.

When Table 6 is examined, it is seen that teachers prefer to use the software and programs they are able to use for the purposes of creating concept map, creating visual material, ensuring participation in the course, creating puzzles, playing games, reinforcement, preparing presentations, preparing questions, increasing permanence, ensuring meaningful learning, drawing attention, making the course entertaining, saving time, making evaluation, concretization. It is seen that they mostly use the mentioned software and programs with the intention of preparing materials $(20.25 \%)$ and preparing presentations (16.98\%) from these categories.

Responses for the question of "What is EIN?" and the content analysis of these responses and the codes and themes determined with the intention of determining the opinions and perceptions for EIN of the teachers who have participated in the study are given in Table 7.

According to Table 7, it is seen that the responses of the teachers to the question

"What is EIN" are collected under five themes: "course content, ready material finding tool for the course contents, platform, module, other".

Under the course content theme, it was determined that the teachers considered EIN as "ready database for course contents", "course content sharing tool" and "course content creating tool". Among these codes, the most notable one is that teachers consider EIN as a means of finding ready material for course contents. The opinion of $\mathrm{S} 42$ in this direction is as follows:

"Morpa campus in EIN is a database containing course books, question pools, and ready materials that facilitate teachers' work."

Similarly, the opinions of S48 are as follows:

"EIN is a ready material finding platform for courses that includes course contents, sample lectures, sample question solutions."

22 teachers see EIN as a ready material finding tool for course content, while 20 teachers see EIN as a means to create course content. On this matter, the opinion of S20 is as follows:

"EIN is the content part of the Fatih project. With EIN, different contents are presented to teachers and students. EIN has e-video, e-magazine, e-audio, e-book, e-content production tools, portals and sharing department. In EIN Course, contents of each course, lectures, animations, interactive contents, tests for teachers and students are provided and ensured that these are produced and shared."

Education Information Network is defined as an online social education platform. One of its aims is to support the use of effective material in education by using information technology tools that offer the opportunity to learn in school or remotely. It also helps the teacher to do better teaching activities when presenting course contents, helps the student to access the necessary course resources, to develop individual learning competences and to make the use of leisure time efficient [5]. Through the e-content module from the modules that constitute the Education Information Network (EIN), content production system enables teachers to develop and upload materials and content suitable for the achievements and transmit them to the students. In this context, the fact that a large proportion of teachers consider EIN as only a tool for preparing ready material for course content, suggests that they do not create content for their students and that they cannot use this feature. Another theme, which is obtained from the opinions of the teachers in a quality supporting this idea, is the "Ready material finding tool". Under this theme, it was determined that the teachers considered EIN as video, slide, test, question, image, activity, reliable material providing tool. The opinion expressed by S3 in this direction is as follows.

"It is a bank for finding information, slides, activities, questions, film tools for students and teachers in education and training." EIN is a system that also includes educational content. Within EIN, there are safe resources in the form of video lectures as well as resources in having the feature of script, audio and image. However, the intended use of EIN is not only to use existing ready materials but to create a rich social sharing platform in the field of education and training. In this respect, the fact that EIN is regarded only as a means of providing ready materials can lead to the failure to achieve the purpose of creating rich material and content sharing. 
Table 7. Codes and themes for the responses of teachers to the question of "What is EIN?"

\begin{tabular}{|c|c|c|c|c|}
\hline Theme & Code & $\mathrm{f}$ & $\%$ & Sample opinion \\
\hline \multirow[b]{3}{*}{$\begin{array}{l}\text { Course } \\
\text { Content }\end{array}$} & $\begin{array}{l}\text { Ready database for } \\
\text { course contents }\end{array}$ & 22 & 8.80 & $\begin{array}{l}\text { S42. Morpa campus in EIN is a database containing course books, question } \\
\text { pools, and ready materials that facilitate teachers' work. }\end{array}$ \\
\hline & $\begin{array}{l}\text { Course content sharing } \\
\text { tool }\end{array}$ & 6 & 2.4 & $\begin{array}{l}\text { S9. EIN is a platform that provides great convenience to teachers and students } \\
\text { in education. Teachers can upload content to EIN whenever they want, while } \\
\text { notes and presentations can easily be shared by other teachers. }\end{array}$ \\
\hline & $\begin{array}{l}\text { Course content creating } \\
\text { tool }\end{array}$ & 20 & 8 & $\begin{array}{l}\text { S20. EIN is the content part of the Fatih project. With EIN, different contents } \\
\text { are presented to teachers and students. EIN has e-video, e-magazine, e-audio, } \\
\text { e-book, e-content production tools, portals and sharing department. In EIN } \\
\text { Course, contents of each course, lectures, animations, interactive contents, } \\
\text { tests for teachers and students are provided and ensured that these are } \\
\text { produced and shared. }\end{array}$ \\
\hline \multirow{7}{*}{$\begin{array}{c}\text { Ready } \\
\text { material } \\
\text { finding } \\
\text { tool }\end{array}$} & Video $\quad(20)$ & 20 & 8 & \multirow{5}{*}{$\begin{array}{l}\text { S16. EIN is a tool for finding questions, videos, tests, images, slides suitable } \\
\text { for course contents. }\end{array}$} \\
\hline & Slide (16) & 16 & 6.4 & \\
\hline & Test (9) & 9 & 3.6 & \\
\hline & Question & 13 & 5.2 & \\
\hline & Image & 8 & 3.2 & \\
\hline & Activity & 10 & 4 & $\begin{array}{l}\text { S3. It is a bank for finding information, slides, activities, questions, film tools } \\
\text { for students and teachers in education and training. }\end{array}$ \\
\hline & $\begin{array}{l}\text { Reliable Material supply } \\
\text { tool }\end{array}$ & 7 & 2.8 & $\begin{array}{l}\text { S53. EIN is a program where we can find all reliable materials about social } \\
\text { studies. }\end{array}$ \\
\hline \multirow{3}{*}{ Platform } & $\begin{array}{l}\text { Electronic learning } \\
\text { platform }\end{array}$ & 6 & 2.4 & S8. It is an electronic learning platform offered for the use of teachers. \\
\hline & $\begin{array}{l}\text { Online social interaction } \\
\text { platform }\end{array}$ & 17 & 6.8 & $\begin{array}{l}\text { S12. It is a platform that provides sharing and interaction between teachers } \\
\text { and students where the contents of primary, secondary and high school } \\
\text { courses and classes are created. }\end{array}$ \\
\hline & $\begin{array}{c}\text { Teacher-student } \\
\text { communication platform }\end{array}$ & 17 & 6.8 & $\begin{array}{l}\text { S32. EIN is a platform for student-teacher communication where all teachers } \\
\text { share material in our country. }\end{array}$ \\
\hline \multirow{2}{*}{ Module } & Evaluation module & 18 & 7.2 & $\begin{array}{l}\text { S38. EIN is an education and training module that can assign homework to } \\
\text { students and follow these in virtual environment. }\end{array}$ \\
\hline & E document module & 12 & 4.8 & $\begin{array}{l}\text { S20.EIN is an e-document containing material such as video, magazine, } \\
\text { audio, book, file. }\end{array}$ \\
\hline \multirow{2}{*}{ Other } & $\begin{array}{c}\text { Tool for ensuring } \\
\text { permanence }\end{array}$ & 36 & 14.4 & $\begin{array}{l}\text { S32. EIN is a technological tool that helps teachers and students to provide } \\
\text { permanence and self-assessment. }\end{array}$ \\
\hline & $\begin{array}{l}\text { Tool for providing } \\
\text { equality of opportunity }\end{array}$ & 13 & 5.2 & $\begin{array}{l}\text { S19. It is a tool that provides equality of opportunity to provide access for all } \\
\text { teachers and students. }\end{array}$ \\
\hline Total & & 250 & 100 & \\
\hline
\end{tabular}

When teacher opinions were examined, it was determined that teachers evaluated EIN as an electronic learning platform, online social interaction platform, teacher student communication platform. The opinion of S12 who defines EIN under the code of on-line social interaction platform is as follows:

"It is a platform that provides sharing and interaction between teachers and students where the contents of primary, secondary and high school courses and classes are created."

Teachers who express opinion under this determined theme do not consider EIN as a tool to find only ready materials, but also as a platform for producing and sharing content and materials. While 18 teachers who express opinion consider EIN as an evaluation module, of teachers who express opinion, 36 consider EIN as a tool for providing permanence and 13 consider EIN as a tool for providing equality of opportunity. The frequency and percentage values of the teachers' opinions on the purpose of using EIN in the teaching of social studies are given in Table 8 .
When Table 8 is examined, it is seen that the teachers' purposes for using EIN are categorized as sharing/providing course content, increasing participation, making the course entertaining, providing visual material, making evaluation, providing reliable material, applying different teaching methods, ensuring integration of technology with education, drawing attention to the course, concretization, providing equality of opportunity, reinforcement, making presentations, technology-supported education, providing permanence, saving time, using it as an auxiliary tool for the course book. It is seen that, the teachers' opinions on their purpose in using EIN are in conformity with the opinions when compared to their purposes of using technology in teaching social studies under the categories of drawing attention, increasing permanence, saving time, ensuring meaningful learning, ensuring concretization, increasing participation in the course, making the course entertaining, reinforcing the subjects, providing aural, visual support, reducing the insufficiency of the course book. It has been determined that, in this direction where teachers' purposes in using 
EIN concentrates mostly on providing visual material, 19 teachers have expressed opinion. In this direction, the opinion of S59 is as follows:

"I think EIN is necessary. I provide that abstract events, objects are concretized and this way, I ensure learning by displaying the video or animation of an event the students have not seen."

When the opinion of S59 is examined, it is seen that he considers EIN as a tool for finding ready documents and prefers to use ready materials on EIN to concretize abstract concepts. When teachers' purpose of using both technology and EIN, it is seen that they prefer to use EIN and technology to eliminate the insufficiency of the course book or to use them as an auxiliary to the course book. This suggests that some of the teachers found the course books to be inadequate. Another one of the highest preference reasons amongst the EIN's usage purposes is on providing visual material such as concretization. In this direction, the opinion of S37 is as follows:

"EIN is a necessary program. All kinds of maps are not available in schools. No relief maps in particular. EIN can be used to provide 3D visual material."

Table 8. Code and themes for EIN Usage Purposes in Teaching Social Studies

\begin{tabular}{|c|c|c|c|}
\hline EIN Usage Purposes & f & $\%$ & Opinion \\
\hline Share/provide course content & 11 & 8.39 & $\begin{array}{l}\text { S46. While it provides convenience for teachers either in lecturing or in reviewing } \\
\text { the course or in doing tests, etc., it is also very beneficial for students in logging in } \\
\text { and accessing information. It ensures that controlled and accurate information is } \\
\text { shared with students. }\end{array}$ \\
\hline Increase participation & 7 & 5.34 & $\begin{array}{l}\text { S52. I use it frequently for the purposes of the active participation of the teacher and } \\
\text { the student at every step of the course and the permanence of knowledge with the } \\
\text { planned processing of the cognitive network, to increase the interest and will of the } \\
\text { student. }\end{array}$ \\
\hline Make the course entertaining & 6 & 4.58 & $\begin{array}{l}\text { S2. The videos, images, magazines can be used to explain the course. I make the } \\
\text { lesson more enjoyable by making it possible for the students to solve the activities. I } \\
\text { also increase participation. }\end{array}$ \\
\hline Provide visual material & 16 & 12.21 & $\begin{array}{l}\text { S37. EIN is a necessary program. All kinds of maps are not available in schools. No } \\
\text { relief maps in particular. EIN can be used to provide 3D visual material. }\end{array}$ \\
\hline Make evaluation & 13 & 9.92 & $\begin{array}{l}\text { S25. According to the course of the lesson, where we consider necessary, for } \\
\text { example in the introduction part, as it can be used to arouse curiosity in the student, } \\
\text { to motivate for the course, it can also be used in the evaluation part to measure } \\
\text { whether the subject is understood. }\end{array}$ \\
\hline Provide reliable material & 4 & 3.05 & $\begin{array}{l}\text { S58. EIN provides accurate, robust, reliable material } \\
\text { that the teacher can safely access. }\end{array}$ \\
\hline $\begin{array}{l}\text { Apply different teaching } \\
\text { methods }\end{array}$ & 5 & 3.81 & S59. I think it would be useful to use EIN to apply different teaching methods. \\
\hline $\begin{array}{l}\text { Provide integration of } \\
\text { technology with education }\end{array}$ & 2 & 1.52 & S13.I use EIN to integrate technology effectively with education. \\
\hline Draw attention to the course & 10 & 7.63 & S5. My purpose of using EIN is to draw more attention to the course \\
\hline Concretization & 19 & 14.50 & $\begin{array}{l}\text { S59. I think EIN is necessary. I provide that abstract events, objects are concretized } \\
\text { and this way, I ensure learning by displaying the video or animation of an event the } \\
\text { students have not seen. }\end{array}$ \\
\hline $\begin{array}{l}\text { Provide equality of } \\
\text { opportunity }\end{array}$ & 4 & 3.05 & $\begin{array}{l}\text { S49. Some of the students do not have access to some resources. Therefore, } \\
\text { supplying materials such as books and magazines from EIN provides equality of } \\
\text { opportunity. }\end{array}$ \\
\hline Reinforcement & 6 & 4.58 & $\begin{array}{l}\text { S15. I use videos, images and maps in EIN to draw attention reinforce and } \\
\text { summarize the subjects. }\end{array}$ \\
\hline Make presentations & 2 & 1.52 & $\begin{array}{l}\text { S41. I have the opportunity to present the course to } \\
\text { the students through video and presentations. }\end{array}$ \\
\hline $\begin{array}{l}\text { Technology-supported } \\
\text { education }\end{array}$ & 3 & 2.29 & $\begin{array}{l}\text { S39. With EIN, technology-supported lessons can be taught. For example, maps or } \\
\text { natural disaster videos are ideal for this. }\end{array}$ \\
\hline Provide permanence & 8 & 6.10 & $\begin{array}{l}\text { S29. Images and natural disaster videos on EIN are more effective and interesting } \\
\text { for students. It also increases permanence. }\end{array}$ \\
\hline Save time & 14 & 10.61 & $\begin{array}{l}\text { S11. Images, videos, presentations and books on EIN help } \\
\text { the lesson to be taught in a shorter time. }\end{array}$ \\
\hline $\begin{array}{l}\text { Use it as an auxiliary tool for } \\
\text { the course book }\end{array}$ & 1 & 0.76 & $\begin{array}{l}\text { S21. I use some videos from EIN as an auxiliary tool for my course book. } \\
\text { Sometimes the images in the course book are insufficient to describe natural } \\
\text { disasters such as earthquakes. }\end{array}$ \\
\hline Total & $\begin{array}{c}13 \\
1\end{array}$ & 100 & \\
\hline
\end{tabular}

S37 stated that he preferred to use EIN to overcome the deficiencies of some of the materials that were difficult to find at school. The result is similar to the results of the research conducted by Türker and Güven [45]. Accordingly, teachers use EIN in dimensions such as reinforcement or visualization of the course. The opinions of the social studies teachers 
about EIN's deficiencies are given in Table 9.

Table 9. Deficiencies of EIN

\begin{tabular}{|c|c|c|c|c|}
\hline Theme & Code & f & $\%$ & Sample opinion \\
\hline \multirow{5}{*}{$\begin{array}{l}\text { Document } \\
\text { Insufficiency }\end{array}$} & Video & 9 & 13.23 & $\begin{array}{l}\text { S58. There are limited number of videos and representations for } \\
\text { 5th,6th and7th grades. EIN should be enriched in this respect. }\end{array}$ \\
\hline & $\begin{array}{l}\text { Evaluation } \\
\text { Questions }\end{array}$ & 13 & 19.12 & $\begin{array}{l}\text { S16. Yes, EIN has deficiencies. There is a test for one unit, not } \\
\text { for one subject. Videos are available on certain subjects. There } \\
\text { aren't videos on all units and subjects. }\end{array}$ \\
\hline & $\begin{array}{l}\text { Visual } \\
\text { Material }\end{array}$ & 1 & 1.47 & $\begin{array}{l}\text { S55. There should be more visual resources, because these are } \\
\text { too inadequate. Reinforcements that can be used outside the class } \\
\text { such as tests, puzzles, activities, films, contests should be } \\
\text { increased. }\end{array}$ \\
\hline & Interactive Exam & 2 & 2.94 & $\begin{array}{l}\text { S10. Deficiencies of EIN; contents should be enriched. } \\
\text { Interactive questions should be increased. }\end{array}$ \\
\hline & Presentation & 2 & 2.94 & $\begin{array}{l}\text { S57. EIN's deficiencies are presentation and video insufficiency, } \\
\text { I cannot reach adequately to any information I want. }\end{array}$ \\
\hline \multirow{4}{*}{$\begin{array}{l}\text { Program } \\
\text { (Conformity with } \\
\text { Achievements) }\end{array}$} & Inadequate Activity & 1 & 1.47 & \multirow{2}{*}{$\begin{array}{l}\text { S59.On EIN, in secondary school section, content, documents } \\
\text { and activities are inadequate. These should be increased. }\end{array}$} \\
\hline & $\begin{array}{l}\text { Document } \\
\text { Deficiency }\end{array}$ & 5 & 7.37 & \\
\hline & $\begin{array}{l}\text { Content } \\
\text { Deficiency }\end{array}$ & 18 & 26.47 & $\begin{array}{l}\text { S53. Content in conformity with the achievements is inadequate, } \\
\text { should be enriched. } \\
\text { S47. I think that it is deficient in terms of content. } \\
\text { S46. The content should be enriched, Encyclopaedia should be } \\
\text { developed, Search Engine should become more effective and fast } \\
\text { in accessing information. }\end{array}$ \\
\hline & $\begin{array}{l}\text { Deficiency in } \\
\text { Evaluation } \\
\text { Questions }\end{array}$ & 6 & 8.82 & $\begin{array}{l}\text { S33. The evaluation and achievement tests are not in conformity } \\
\text { with the achievements, the factual videos about the subject are } \\
\text { not included. } \\
\text { S30.Some of the evaluation questions are not aimed at purpose. } \\
\text { Content can be prepared in a more professional style. }\end{array}$ \\
\hline \multirow{3}{*}{ Technics } & $\begin{array}{l}\text { Content Not } \\
\text { Being Updated }\end{array}$ & 1 & 1.47 & $\begin{array}{l}\text { S32. Content can be enriched. There are still images and videos } \\
\text { of old subjects. Evaluation activities need to be more. }\end{array}$ \\
\hline & $\begin{array}{c}\text { YouTube-internet } \\
\text { connection Access } \\
\text { Barrier } \\
\end{array}$ & 1 & 1.47 & $\begin{array}{l}\text { S51.EIN's biggest deficiency is that the access and internet } \\
\text { infrastructure problems have not been solved yet. }\end{array}$ \\
\hline & $\begin{array}{l}\text { The fact that students } \\
\text { are not informed } \\
\text { when } \\
\text { questions-subjects are } \\
\text { uploaded to EIN }\end{array}$ & 1 & 1.47 & $\begin{array}{l}\text { S11. There should be a section for individual work in the EIN } \\
\text { system and a message system to inform the student when the } \\
\text { subjects and questions are uploaded to EIN. }\end{array}$ \\
\hline \multirow{2}{*}{$\begin{array}{l}\text { Inadequate practice } \\
\text { and training }\end{array}$} & $\begin{array}{l}\text { Inadequacy of } \\
\text { teachers in sharing } \\
\text { their experiences }\end{array}$ & 2 & 2.94 & $\begin{array}{l}\text { S9. EIN does not give a very detailed place to the source material } \\
\text { in terms of content, at the same time it does not make a sufficient } \\
\text { contribution to the sharing of knowledge and experience of all } \\
\text { teachers. }\end{array}$ \\
\hline & $\begin{array}{l}\text { In-service training } \\
\text { deficiency }\end{array}$ & 6 & 8.82 & $\begin{array}{l}\text { S2. The only deficiency is that teacher and student participation } \\
\text { is not at the expected level and there is a lack of in-service } \\
\text { training on EIN }\end{array}$ \\
\hline Total & & 68 & 100 & \\
\hline
\end{tabular}

When Table 9 is examined, it is seen that the teachers' opinions on the deficiencies of EIN are collected under the themes of Document Deficiency, Program (Content's Conformity with the Achievements), Technical problems and inadequate practice and training deficiency.

When the opinions of the teachers were examined, it was determined that some teachers have not given any idea about EIN's deficiencies because they did not know it. In addition, some teachers have indicated that they find the EIN system too complex. Some teachers argue that EIN influences in-class practices. In this direction, the opinion of $\mathrm{S} 60$ is as follows:
"Teacher should not be ignored while EIN is used, because the use of EIN in class can affect the use of teaching methods and techniques."

When the opinion of S60 is examined, it stands out that he has worries about using EIN in replacement of a teacher. In this direction, it is thought that he lacks information on for what purposes a teacher is expected to use EIN.

It is seen that, teachers, mostly, draw attention to the deficiency of content in conformity with achievements in the program. In this direction, the opinion of S40 is as follows:

"EIN also has content deficiencies for achievements. In 
some achievements, there is a resource only as a reading of the information contained in the course book. This is an insufficient and unnecessary content. Content such as animations and short films should be increased."

When teachers' opinions are examined, it is seen that they have expressed opinion that EIN had positive opinions on implementation of EIN in the teaching environment but that there were problems with updating, conformity with achievements, technical problems and deficiencies in the level of sharing of teacher's experiences.

\section{Conclusions}

This study examined the opinions of social studies teachers towards EIN. To this end, questions were asked to teachers about the use of technology in teaching social studies and their purposes of use, what EIN is, for what purpose they use EIN in teaching social studies, and what deficiencies they see in EIN.

As a result of the research, it was determined that the frequency of using the technology in teaching social studies is $88.33 \%$ and the level of using EIN is $23.30 \%$. Nevertheless, teachers' purpose of using technology in teaching social studies are determined to be in the direction of goals such as increasing permanence, drawing attention, increasing motivation, saving time, concretization, facilitating teaching, increasing participation in the course, making evaluations, reinforcing subjects, making presentations, reducing workload, learning by making and experiencing, providing aural and visual support, summarizing the course and displaying videos.

When their opinions regarding their EIN usage purposes in teaching social studies are compared to their technology usage in teaching social studies, it is seen that these are in conformity and similar themes come forward. It has been determined that their opinions under the categories of drawing attention, increasing permanence, saving time, ensuring meaningful learning, ensuring concretization, increasing participation in the course, making the course entertaining, reinforcing the subjects, providing aural and visual support, reducing the insufficiency of the course book are commonly parallel. In addition, regarding the question of 'What is EIN?' asked to teachers, it has been determined that the teachers consider EIN as a ready database for course contents, a course content sharing tool and "a course content creating tool", "a tool for providing ready materials such as videos, slides, tests, questions, images, activities", "an electronic learning platform", "an online social interaction platform", "a teacher-student communication platform", "an evaluation module", "an e-document module" or "a tool for providing equality of opportunity". When EIN is examined, as well as providing reliable material, document, video, interactive video and file adding systems are available in material section in the content management system; activity, animation and lecture video and summary document adding systems are available in the interactive activity and lecture section. Also, opportunity of creating learning steps by using interactive activity and lectures in Learning section; producing interactive multiple choice, open-end questions in Questions section; creating one's own exam in the Exams section; creating interactive activity and lectures in the Vitamin Factory section is provided. However, the Social Studies teachers' usage purpose of EIN and their perception towards EIN indicates that EIN is considered only as a tool for providing ready material and as a course content ready data base $(42 \%)$. It has been determined that teachers do not use the modules in EIN and that they do not prepare course flows, questions and interactive applications for their students. When considered from this point of view, 39, 7\% of the deficiencies stated for EIN are focused on deficiency of ready documents, which supports this view. Similar to the results obtained, studies in the literature show that, even though it cannot be sufficiently used by the teachers due to problems such as internet connection, the teachers use EIN in their classes in dimensions such as reinforcing or visualising the course Turker \& Guven, the teachers cannot find appropriate materials for their lectures on EIN, due to the fact that EIN is not enriched enough, it is necessary to recreate auxiliary materials such as videos, visuals, animations related to course subjects, etc., [46]. As seen in the results of the study, it has been determined that other teachers such as social studies teachers do not use EIN frequently and criticize EIN for having inadequate content and therefore it is partly effective and efficient in terms of teaching [46,47]. As it can be seen, either teachers of social studies or teachers who work in other branches do not have enough knowledge about Educational Information Network (EIN). It is also seen that some of the teachers believed that EIN should have content for each course and they expect that this content should be provided by MNE. However, EIN is not a goal but a tool for teaching. Also, if the evaluations, videos, exams or interactive contents, digital materials such as sound and image files, achievements from the teachers are developed by the teacher himself/herself by taking into consideration many factors such as student characteristics and teaching methods, contents suitable to use in course may be created. Another noteworthy result of the study is that the purpose of using EIN in the courses is similar to the purpose of teachers using technology in their courses. For this reason, providing that EIN or another platform is used correctly is believed to be associated with the perceptions of teachers on the use of technology in education. In addition, it may be helpful for the proper use of applications such as EIN to increase the skills of teachers in digital content development and to make them conscious and competent about ways to effectively integrate technology into the course. In this context, it is suggested to provide practical in-service training to teachers in the frame of innovative teaching approaches, to 
take more consideration of the teachers' recommendations so that EIN has a more effective e-content, to increase teachers' sharing of the contents they developed and to conduct introduction and encouragement activities for EIN to raise teacher awareness.

\section{Acknowledgements}

This study was presented in Globets: An International Conference On Education, Technology And Science, Which Will Be Held On 6 - 9 May 2018 In Belgrade, Serbia.

\section{REFERENCES}

[1] J. R. Chapin, R. G. Messick, Elementary School Studies. New York, Longman. 1999.

[2] MNE (Ministor of National Education) Program of Social Studies. Talim Terbiye Kurulu, Retrieved from http://mufredat.meb.gov.tr/ProgramDetay.aspx?PID=354, 2017.

[3] Prensky, M. Digital natives, digital immigrants' part 1. On The Horizon, 9(5), 1-6, 2001.

[4] Akkoyunlu, B. Educational technology in Turkey: Past, present and future. Educational Media International, 39(2), 165-174, 2002.

[5] Kaya, N. Sosyal Bilgiler Öğretiminde Interaktif (Etkileşimli) Bilgisayar Destekli Öğretimin Öğrenci Başarısına Etkisi. Unpublished Master Thesis, Yeditepe University, Istanbul, 2008.

[6] MNE (Ministor of National Education) FATİH Projesi Hakkında. Online available from $\mathrm{http} / / /$ fatihprojesi.meb.gov.tr/tr/icerikincele.php?id=6 adress., 2014.

[7] Tinmaz, H. Social networking websites as an innovative framework for connectivism. Contemporary Educational Technology, 3 (3), 234-245, 2012.

[8] Maloney, E. What Web 2.0 Can Teach Us About Learning, Chronicle of Higher Education, 18: B26., 2007.

[9] Selwyn, N. Face working: exploring students' education-related use of Facebook. Learning, Media and Technology, 34 (2), 157, 2009.

[10] EBA. Eğitim Bilişim Ağı.: Online available from, http://www.eba.gov.tr/.2018.

[11] Digregorio, P. ve Lojeski, S. K. The Effects of Interactive White Boards (IWB) on Student Performance and Learning: A Literature Review. J. Educational Technology Systems, 38(3), 255-312, 2010.

[12] Kearney, M. ve Schuck, S. Exploring Pedagogy With Interactive White Boards in Australian Schools. Australian Educational Computing, 23(1),8-14,2008.

[13] Hylén, J., Van Damme, D., Mulder, F., \& D'Antoni, S.
Open Educational Resources: Analysis of responses to the OECD country questionnaire. OECD Education Working Papers, 76, 2012.

[14] Johnson, L., A., Becker, S., Estrada, V., \& Freeman, A. NMC Horizon Report: 2014 K-12 Edition. Austin, Texas: The New Media Consortium, 2014.

[15] Willems, J., \& Bossu, C. Equity considerations for open educational resources in the glocalization of education. Distance Education, 33(2), 185-199, 2012.

[16] Mulder, F. Open(ing up) education for all boosted by MOOCs? In C.J. Bonk, M. M. Lee, T. C. Reeves, \& T. H. Reynolds (Eds.), MOOCs and open education around the world. New York, NY: Routledge. Retrieved from http://www.eadtu.eu/documents/Publications/OEenM/Fore word MOOCs_Book--Fred-Mulder_OU_Netherlands.pdf, 2015.

[17] Geser, G. (Ed.). Open educational practices and resources, OLCOS roadmap 2012. Salzburg, Austria: Salzburg Research Edumedia Research Group. Retrieved from http://www.olcos.org/cms/upload/docs/olcos_roadmap.pdf, 2007.

[18] Butcher, N., \& Hoosen, S. Exploring the business case of open educational resources. Vancouver, Canada: Commonwealth of Learning, 2012.

[19] Sclater, N. Open educational resources: Motivations, logistics and sustainability. In Ferrer, N.F. \& Alfonso, J. M. (Eds.), Content management for e-learning, (pp. 179-193). New York, NY: Springer, 2011.

[20] Goldberg, E. J., \& La Magna, M. Open educational resources in higher education: A guide to online resources. College \& Research Libraries News, 73(6), 334-337, 2012.

[21] Mesquita, L. The entrepreneurialisation of school work as a central theme in present educational changes: the Portuguese case. Journal of Educational Administration and History, 44(2), 141-153, 2012.

[22] National Plan for Educational Use of Information and Communications Technology, http://www.edu.fi/download/135308_TVT_opetuskayton suunnitelma_Eng.pdf, 2010.

[23] Malaysia, M.O.E. Preliminary Report: Malaysia Education Blueprint 2013-2025, Ministry of Education Malaysia, Malaysia, 2012.

[24] Tekin, A., \& Polat, E. Technology Policies In Education: Turkey And Several Other Countries. Journal of Theory \& Practice in Education (JTPE), 10(5), 2014.

[25] Education Services Australia. Scootle. Retrieved, from http://www.scootle.edu.au/, 2013.

[26] Dussel, I., Ferrante, P., \& Sefton-Green, J. Changing narratives of change: (un) intended consequences of educational technology reform in Argentina. In The politics of education and technology (pp. 127-145). Palgrave Macmillan, New York, 2013.

[27] Ozdemir, O., \& Bonk, C. Turkish Teachers' Awareness and Perceptions of Open Educational. Resources. The Journal of Learning for Development, 4(3), 307-321, 2017.

[28] Kurtdede Fidan, N., Erbasan, Ö. \& Kolsuz, S. Sinıf 
Öğretmenlerinin Eğitim Bilișim Ağı'ndan (EBA) Yararlanmaya İlişkin Görüşleri. Journal of International Social Research, 9(45), 2016.

[29] Demircioğlu, G., \& Yadigaroğlu, M. Kimya Öğretmenlerinin Fatih Projesine İlişskin Görüşleri. Journal of Research in Education and Teaching, 3(2), 2014.

[30] Pamuk, S., Çakır, R., Ergun, M., Yılmaz, H. B. \& Ayas, C. Öğretmen ve öğrenci bakış açısılyla tablet pc ve etkileşimli tahta kullanımı: Fatih projesi değerlendirmesi. Educational Sciences: Theory \& Practice 13 (3), 1799-1822, 2013.

[31] Aslan, Z. Eğitim bilişim Ağı'ndaki matematik dersi içeriğine ilişkin öğretmen görüşleri: Trabzon ili örneği. Unpublished Master Thesis, Gazi University, Ankara,2016.

[32] Çakmak, Z., \& Taşkıran, C. Sosyal Bilgiler Öğretmenlerinin Perspektifinden Eğitim Bilişim Ağı (EBA) Platformu. International Journal of Turkish Education Science, (9), 284-295, 2017.

[33] Alabay, A. Ortaöğretim öğretmenlerinin ve öğrencilerinin eba (eğitimde bilişim ağı) kullanımına ilișkin görüşleri üzerine bir araştırma, Unpublished Master Thesis, İstanbul Aydın University, İstanbul., 2015.

[34] Christensen, R., Knezek, G.,Tyler-Wood. T. Student Perceptions of Science, Technology, Engineering and Mathematics (STEM) Content and Careers, Computers In Human Behavior, 34, s. 173-186, 2014.

[35] Albirini, A. Teachers' attitudes toward information and communication technologies: The case of Syrian EFL teachers. Computers \& Education, 47(4), 373-398, 2006.

[36] Bingimlas, K. A. Barriers to the successful integration of ICT in teaching and learning environments: A review of the literature. Eurasia Journal of Mathematics, Science \& Technology Education, 5(3), 2009.

[37] Hew, K. F., Brush, T. Integrating technology into K-12 teaching and learning: Current knowledge gaps and recommendations for future research. Educational technology research and development, 55(3), 223-252, 2007.

[38] Tondeur, J., van Braak, J., Ertmer, P. A., \&
Ottenbreit-Leftwich, A. Understanding the relationship between teachers' pedagogical beliefs and technology use in education: a systematic review of qualitative evidence. Educational Technology Research and Development, 65(3), 555-575, 2017.

[39] Creswell, J. W. Reseach Design: Qualitative, Quantitative and Mixed Approaches. (2nd ed.). Newbury Park, CA: Sage, 2002.

[40] Yıldırım, A., Şimek, H. Sosyal Bilimlerde Nitel Araştırma Yöntemleri. Ankara: Seçkin Press, 2005.

[41] Miles, B., M., Huberman, A., M. Data management and analysis methods. N. K. Denzin, Y. S. Lincoln (Ed.). Collecting and interpreting qualitatative materials (s.1 79-210). Thousand Oaks: Sage Pub, 1998.

[42] Tutar, M. Eğitim Bilişim Ağı (Eba) Sitesine Yönelik Olarak Öğretmenlerin Görüşlerinin Değerlendirilmesi, Unpublished Master Thesis, Karadeniz Teknik Univesity, Trabzon, 2015.

[43] Güvendi, G.M. Millî Eğitim Bakanlığı'nın Öğretmenlere Sunmuş Olduğu Çevrimiçi Eğitim Ve Paylaşım Sitelerinin Öğretmenlerce Kullanım S1klığının Belirlenmesi: Eğitim Bilişim Ağı (Eba) Örneği, Unpublished Master Thesis, Sakarya University, Sakarya., 2014.

[44] Bayar, M. F., Kurt, M., Hasiloglu, M. A. Science and Technology Course in Educational Information Network: A Review on Videos. Universal Journal of Educational Research, 6(3), 413-420, 2018.

[45] Türker, A., Güven, C. Lise öğretmenlerinin eğitim bilişim ağ1 (EBA) projesinden yararlanma düzeyleri ve proje ile ilgili görüşleri. Journal of Research in Education and Teaching, 5(1), 244-254, 2016.

[46] Keleş, E., Turan, E. Öğretmenlerin firsatları arttırma ve teknolojiyi iyileştirme hareketi (FATİH) hakkındaki görüşleri. Turkish Journal of Education, 4(2), 17-28., 2015.

[47] Aksoy, N. EBA(eğitim bilişìm ağı)' nın kullanım amacı, karşılaşılan sorunlar ve çözüm önerileri, Unpublished Master Thesis, Kahramanmaraş Sütçü imam University, 2018. 